\title{
THE SELECTED RESULTS OF THE EXPERIMENTAL RESEARCH OF SOLID FUEL PNEUMATIC TRANSPORTATION TO SHIP'S BOILER
}

\author{
Thomas LUSCHTINETZ \\ Hochschule Stralsund \\ Wojciech ZEŃCZAK, Daniel ŁUSZCZYŃSKI \\ West Pomeranian University of Technology
}

\begin{abstract}
:
The article presents the problems related to the application of alternative fuel like solid biomass in the shipbuilding. The decreasing resources of the crude oil, the requirements regarding environmental protection as well as the increase of the liquid fuel prices were the reason for the study. The solid biomass comparing to the liquid or gaseous forms has relatively low calorific value. In order to increase this value the solid biomass is subject to the densification or torrefaction process and most often occurs in the shape of pellets. In this form it could be useful on ships. A test stand has been characterised where it can be experimentally verified whether ship's rolling does affect the changes in flow resistance values during the pneumatic transportation of solid fuel from the storage facility to the boiler. On the basis of the measurements the hydraulic characteristics have been provided for the piping located on the movable platform with and without granular material. The changes in the platform oscillation period have influence on the change in the pressure inside transport piping for each investigated material. The results also show that the platform constantly inclinations do exert an influence on the pressure drop in the transport pipeline during transporting the granular material. It is smaller when the position is inclined. Comparing the results obtained for the different transported materials of a similar nature of the pressure fluctuations could be observed.
\end{abstract}

Key words: ship's power plant, ship's boiler, solid fuel, pneumatic transportation

\section{INTRODUCTION}

In view of the decreasing process of the non-renewable energy sources, in particular crude oil, which is used for the production of ship's fuel, it is necessary to conduct research oriented toward the prevailing application of the alternative fuels as well as the renewable energy sources. The energy sources likely to be applied on ships, ultimately or temporarily, are amongst others: the liquefied natural gas, liquid biofuels such as biomethanol as well as solid biofuel in the form of the pellets [9]. A factor in favour of the utilisation of the liquefied natural gas as the alternative fuel for the ships is the fact that it contains scarce amounts of sulphur [14]. Another benefit of this fuel is that during its combustion the emission of nitrogen oxides is smaller in comparison to the conventional fuels by approximately $80 \%$, emission of carbon oxide by circa $75 \%$. The emission of carbon dioxide is less by about $20 \%$ [6]. Also the gas price is of significance as it is currently lower than the price of heavy diesel oil and marine diesel oil of low sulphur content [12].
Advantage of the methanol as an alternative fuel which may be used in the shipbuilding on a larger scale is the fact that it does not emit sulphur oxides during combustion whereas the emission of nitrogen oxides is compliant with the obligatory requirements of MARPOL Convention. The emission of solid particles is very low. The methanol price, in comparison with hydrocarbon fuels with low sulphur content is lower [8]. An important factor in favour of these fuels is also the existence of biogenic equivalents in the form of biogas and biomethanol.

The solid biomass comparing to the liquid or gaseous forms has relatively low calorific value. In order to increase this value the solid biomass is subject to the densification or torrefaction process and most often occurs in the shape of pellets. The torrefaction process consists in the exposure of the biomass to the 200 up to $400^{\circ} \mathrm{C}$ temperature without oxygen supply, under pressure close to atmospheric. 
Following the solid biomass torrefaction process its calorific value reaches as far as $21 \mathrm{MJ} / \mathrm{kg}$. A biomass advantage is that it contains very minor amounts of sulphur compounds ( $0.5 \%$ dry mass) [4]. Another benefit of the wooden biomass is that during its combustion the $\mathrm{CO}_{2}$ emission does not contribute to the greenhouse effect [7]. Solid biomass in the form of the waste wood, agricultural product waste or energy crops may be used as an alternative marine fuel, because its application allows inter alia to satisfy the requirements in respect of exhaust gas emissions according to MARPOL convention [4]. It may be regarded as a reserve or temporary renewable energy source at the time until the other energy sources, such as [hydrogen supplied] fuel cells, capable of substituting the presently used hydrocarbon fuels, become fully ready for the universal application on ships. The solid biomass has also become the alternative for biogas and biomethanol which require complex installations and protective means due to low flash point.

The lack of reports regarding the solid biofuel pellets use as an energy source for the ships and lack of any references as to the manner of its transportation from the daily storage facility to the ship's boiler consists a cause to commence research in this area [10]. Justification of the topics of the research, specifications of various solid fuel transport installations together with the concept of the research/test stand have been presented by the authors in [9] whereas in [11] the issue of mathematical modelling of the pressure drop phenomenon in the transport piping during ship's rolling has been discussed and the mathematical model used for this phenomenon description has been proposed. The research of similar subjects conducted so far concerned inter alia the pressure drop in the transport pipeline during transportation of granular material in microscale without consideration of the movement of the whole transport installation [13]. Other researches concerned hydrodynamics of a fluidized bed on floating marine systems [1, 2, 3]. Many works are focused on the use of CFD simulation of gas-solid two-phase flows [2, 5, 15]. The purpose of this article is to present the selected results of the research aiming to determine the effect of the simulated ship's sailing conditions onto the pressure drop in the transport section of the piping connecting the storage facility with the boiler. Owing to the dimensions of the stand the materials imitating the solid fuel (pellets) are wheat or rice grains.

\section{TEST STAND}

The construction of the stand enables to set the platform in motion together with the transport installation located thereon. The platform movements may simulate ship's rolling and upon turning by $90^{\circ}$ against the base - pitching (ship's longitudinal motion). The test stand in two projections is shown in Figures 1 and 2.

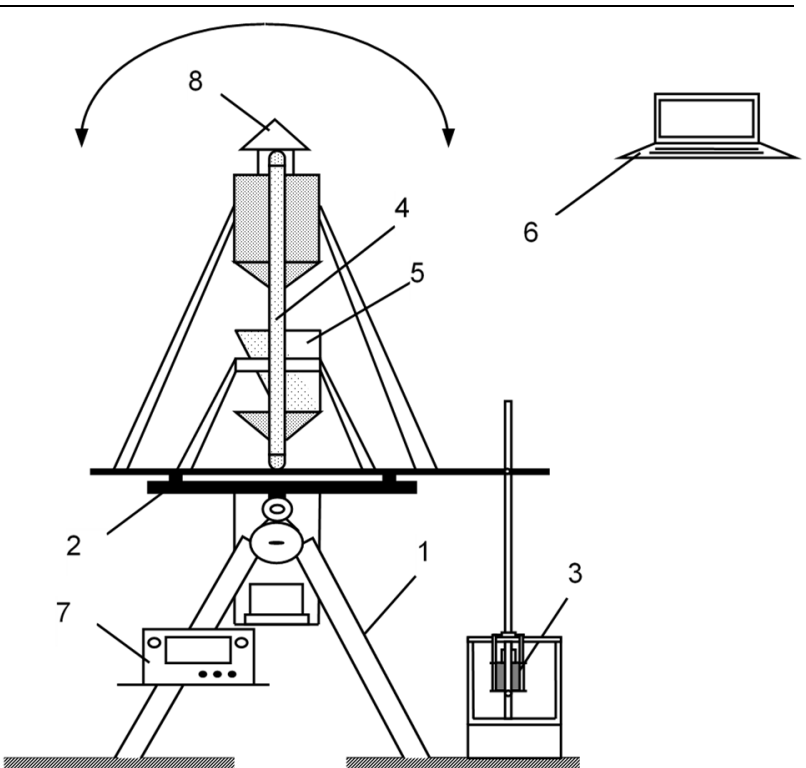

Fig. 1 Test stand for solid fuel pneumatic transportation (front view):

1 - platform base, 2 - movable platform, 3 - electric screw actuator, 4 -transport pipes, 5 -tanks, 6 - portable computer to register the measurements data, 7 - actuator power pack, 8 -cyclone air outlet

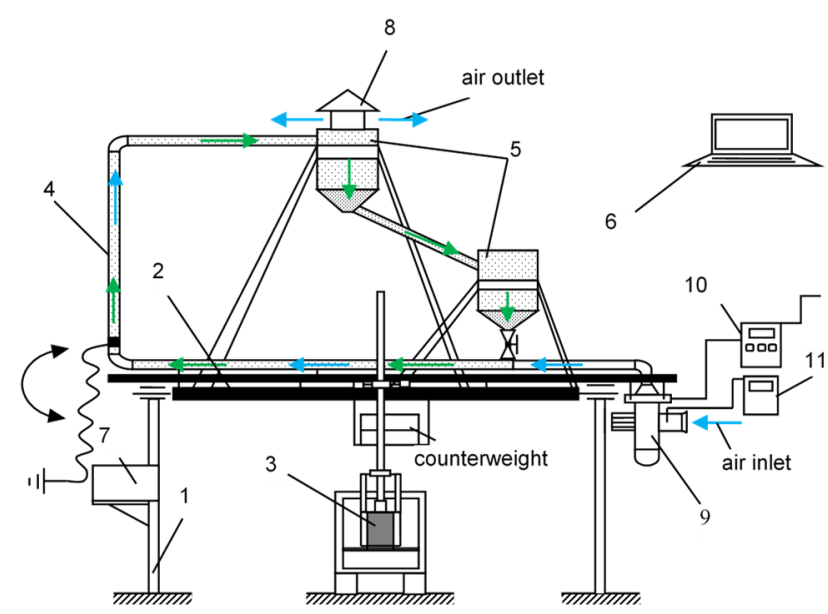

Fig. 2 Test stand for solid fuel pneumatic transportation (side view):

1 - platform base, 2 - movable platform, 3 -electric screw actuator, 4 - transport pipes, 5 - granular material tanks, 6 portable computer to register the measurements data, 7 - actuator power pack, 8 - cyclone air outlet, 9 - radial air blower, 10-differential pressure gauge, 11 - thermo-anemometer

\section{RESEARCH STAGES}

The detailed research programme has been described in [10]. Presently we refer to the research stage with the platform movement taken into consideration. This stage consists of two parts. The purpose of the initial part of the measurements is to determine the relation of the pressure drop to the variable period of platform oscillation $\Delta p=f(T)$

$$
\left.T=v a r, \quad \begin{array}{c}
t_{a} \\
\dot{m}
\end{array}\right\}=\text { idem. }
$$

The purpose of the second part of the measurements is to determine the relation of pressure drop to the change of 
the fuel mass amount with the constant period of platform oscillation $\Delta p=f(\dot{m})$;

$$
\left.\dot{m}=\text { var }, \quad \begin{array}{c}
t_{a} \\
w
\end{array}\right\}=\text { idem, }
$$

where:

$T$ - platform oscillation period,

$\dot{m}$-transported material jet,

$w$ - two-phase mixture velocity,

$t_{a}$ - air temperature.

\section{THE SELECTED RESEARCH RESULTS}

The measurements conducted on the stand with the immobile platform referred to various positions, ie vertical, $\left(0^{\circ}\right.$ angle) and with deflection by $30^{\circ}$ angle. On the basis of the results the hydraulic characteristics have been provided for the piping without and with granular material, the minimum transport velocities of the granular material have been determined, definition was provided for the pressure drops in relation to the transported fuel mass amount, pressure drops for various inclination angles of the installation have been determined. During the measurements also characteristics have been provided and compared for the two granular materials, wheat and rice. The amount of granular material was changed by alteration of the opening of the valve 6 . The range of valve opening change was within $72 \%$ and $89 \%$.

The Fig. 3 demonstrates the relation of the pressure drop in the installation in vertical position for two granular materials $\Delta p=f(w)$.

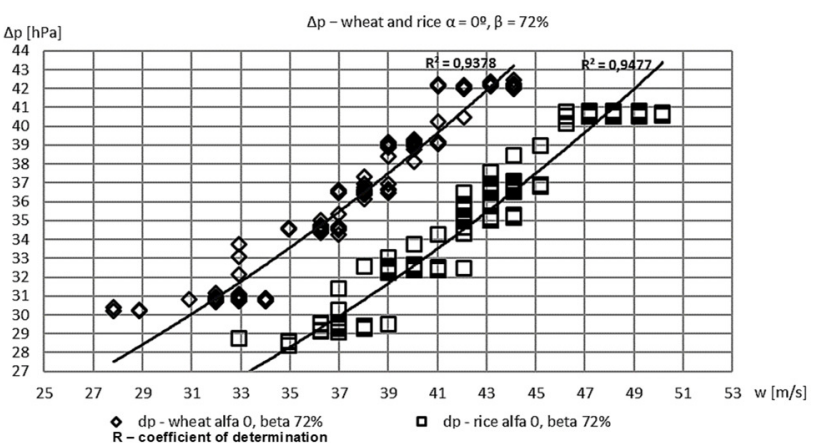

Fig. 3 Flow resistance values in pipeline during transport of wheat or rice

The graph where the hydraulic characteristics for the two granular materials were presented enables to compare the difference in the values of pressure drops between wheat and rice. The graph shows clearly the difference in pressure drops which is caused by the fact that a single wheat grain has slightly bigger dimensions than rice grain. The discernible difference in pressure drops between the two granular materials may also result from the difference in roughness of wheat and rice. During the determination of the characteristics $74 \%$ valve opening ensures the granular material flow without saltation.

In the Fig. 4 there is shown the relation of pressure drop to the various installation inclination angles for the two granular materials $\Delta p=f(\alpha)$.

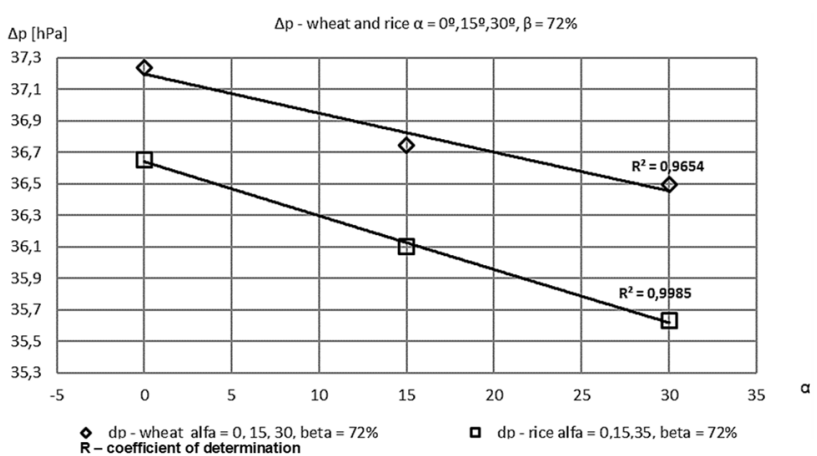

Fig. 4 Pressure drop in relation to the platform inclination angle for various materials

The analysis of the measurement results on the stand with the stationary platform (Fig. 4) allows to observe the pressure change during the transport of granular material of rice and wheat, depending on the change in the platform positioning angle. In the measurements three inclination angles have been considered with the permanent mass capacity of granular material. In the graph (Fig. 4) one can observe that the pressure reaches its biggest value when the platform is in vertical position ( $0^{\circ}$ angle). Change of platform position angle by $15^{\circ}$ and $30^{\circ}$ causes insignificant pressure drop. This minor pressure change is caused by the reduction in the difference of the height to which the granular material is transported.

In the Fig. 5 on the radar graph there has been shown the relation of pressure drop during platform movement for rice $\Delta p=f(\alpha)$.

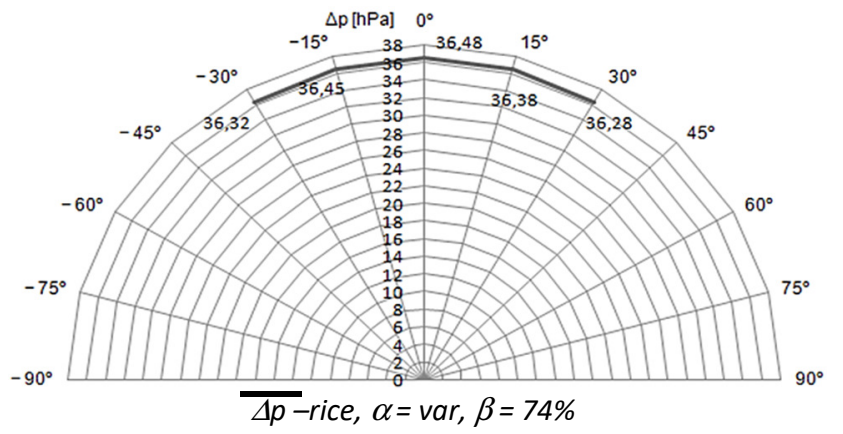

Fig. 5 Pressure drop during platform movement for rice

The graph presents the average momentary values of the pressure drop for rice, with the constant opening of the inlet valve and constant period of the platform oscillation. These are the averaged values of the pressure drops as the platform is inclined by $15^{\circ}$ and $30^{\circ}$ angle and $-15^{\circ}$ and $-30^{\circ}$ as well as in vertical position during constant pendular movement. As can be seen, when the installation is in vertical $\left(0^{\circ}\right.$ angle) the value of the pressure drop in the pipeline reaches its maximum value. The measurements on the stand with the movable platform and with the constant period of the platform oscillation with one granular material confirm the earlier results of the research conducted in the stationary conditions with one granular material. They also implied that the platform inclinations do exert an influence on the pressure drop in the transport pipeline while transporting the granular material. It is smaller while the position is inclined. 
The growing sectional area of the supply valve opening is accompanied by the increase in the capacity of the pneumatic transport.

The results of measurements which purpose has been to determine the relation of the pressure drop to the change in fuel dose amount with the constant period of platform oscillation $\Delta p=f(\dot{m})$, are shown in Fig. 6 .

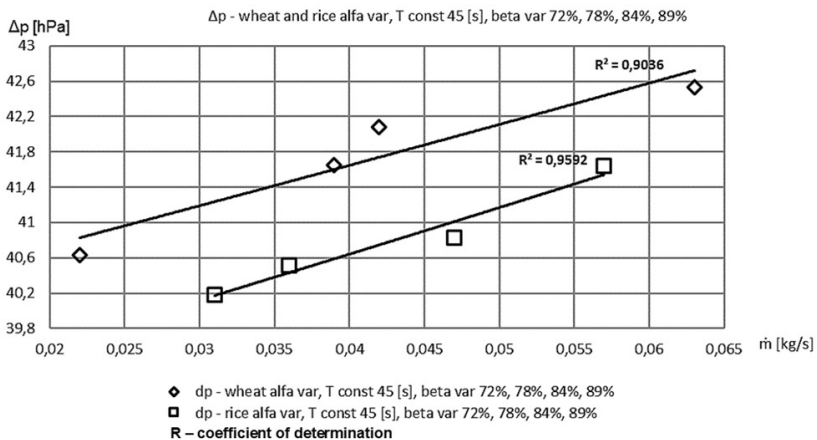

Fig. 6 Pressure drop in relation to the change of the jet of the material dose amount

In the graph there are shown relations for two granular materials, wheat and rice. It can be concluded that the flow resistance values for the wheat are slightly bigger because wheat has bigger density. On the basis of the research conducted the maximum valve opening has been determined as amounting to $89 \%$, since with the bigger opening flow saltation appears. With the valve maximum opening (ie. $89 \%$ sectional area) the maximum capacity has been achieved when no saltation occurs.

The results of the measurements which purpose was to determine the relation of the pressure drop in time and to the variable period of platform oscillation $\Delta p=f(T)$, are shown in Fig. 7.

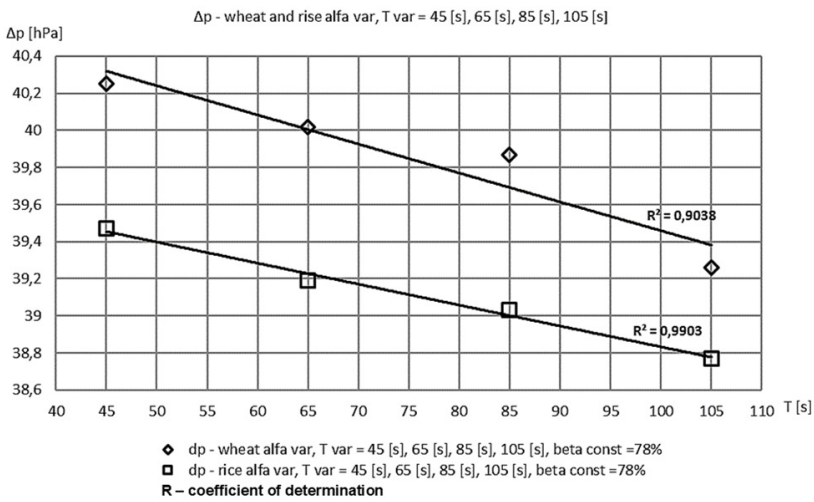

Fig. 7 Pressure drop in relation to the change in platform oscillation

The graph shows the changes in the pressure of two granular materials caused by the change of the period in the simulated sideways rolling, for four different period values, with the constant mass capacity.

In the graph one can see that the changes in the platform oscillation period have influence on the change in the pressure inside transport piping for both wheat and rice. As the periods of movements increase, the resistance values decrease and reach the minimum values once the platform is stopped.
The values of determination coefficient showed on all the graphs are in the range of 0.9-1.0. This indicates a very good fit of the trend lines.

\section{CONCLUSION}

The presented selected results of measurements taken on the stand with the stationary platform have proven that the platform inclination angle change by $15^{\circ}$ and $30^{\circ}$ influences but slightly the pressure drop in the piping. The difference of pressure resistance values between platform position angle of $0^{\circ}$ and $30^{\circ}$ amounted to $74 \mathrm{~Pa}$. The results obtained from the measurements conducted on the stand with the movable platform also indicate a minor pressure drop during change of the dose of granular material as well as the changes of the period in the simulated rolling. At the stand with the movable platform the results of measurements which aimed to determine the dependence of the pressure drop on the change of the platform oscillation period, have shown very small pressure drop in the transport pipeline accompanying the decrease of the period of platform oscillation. While comparing the results obtained for the transported wheat, followed by those from the transportation of rice, a similar nature of the pressure fluctuations for both materials can be observed.

\section{REFERENCES}

[1] G.P. Assima, A.M. Dashliborun, F. Larachi. "Emulation of Gas-Liquid Flow in Packed Beds for Offshor Floating Applications Using a Swell Simulation Hexapod". AIChE Journal, Vol. 61, No. 7 pp. 2354-2367, July 2015.

[2] A.M. Dashliborun, M. Hamidipour, F. Larachi. "Hydrodynamics of inclined packed beds under flow modulation CFD simulation and experimental validation", AIChE Journal, vol. 63, No. 9 pp. 4161-4176, Sept. 2017.

[3] A.M. Dashliborun, F. Larachi, M. Scubert. "Hydrodynamics of gas-liquid cocurrent upflow in oscillating packed beds for offshore marine applications", Chemical Engineering Science, Vol. 170, pp. 583-596, Oct. 2017.

[4] T. Hardy, A. Piotrowska-Musialik, J. Ciołek, K. Mościcki, W. Kordylewski. (2010). Negatywne efekty zwiqzane ze spalaniem i współspalanie biomasy w kotłach, [On- line], pp. 145-146. Available: www.pzits.not.pl/docs/ksiazki/ Pol_2010/Hardy\%20145-152.pdf [Nov. 26, 2018].

[5] I. Iliuta, F. Larachi. "Two-fluid simulation of liquid drainage in oscillating packed beds for offshore floating applications", Chemical Engineering Science, Vol. 149, pp.1-62, July 2016.

[6] T. Kniaziewicz, L. Piaseczny. "Wybrane aspekty stosowania okrętowych dwupaliwowych silników spalinowych". Combustion Engines, no. 1(148), pp. 25-34, Jan. 2012.

[7] M. Kratofil , R. Zarzycki, R. Kobyłecki, Z. Bis. "Analiza procesu toryfikacji biomasy", Scientific letters of Rzeszow University of Technology, Mechanika, vol. 32 letter 87, no. 2 pp. 119-126, April-June 2015.

[8] W.M. Lewandowski, M. Ryms, Biopaliwa. Proekologiczne odnawialne źródła energii. WNT, 2013, p. 384.

[9] D. Łuszczyński, W. Zeńczak. "Transport pneumatyczny paliwa stałego do kotła w warunkach morskich". Zeszyty Naukowe Akademii Marynarki Wojennej. No. 4(199), pp. 39-50, 2014. 
[10] D. Łuszczyński, W. Zeńczak. "Wstępne wyniki badań eksperymentalnych transportu pneumatycznego paliwa stałego do kotła okrętowego," in Wybrane problemy eksploatacji siłowni okrętowych. Matuszak, Ed Szczecin: Wydawnictwo Naukowe Akademii Morskiej, 2016, pp. 175187.

[11] D. Łuszczyński, W. Zeńczak. "Selection of the Mathematical Model for the Description of Solid Fuel Pneumatic Transport to Ship Boiler". Scientific Journals of the Maritime University of Szczecin, 48(120), pp. 22-28, 2016.

[12] M. Matczak. "Wykorzystanie LNG jako paliwa żeglugowego na Morzu Bałtyckim - przesłanki stosowania, kierunki rozwoju oraz formy wsparcia". Problemy Transportu i Logistyki, 30, pp. 73-85, 2015.

\section{Thomas Luschtinetz}

Hochschule Stralsund, Germany

Faculty of Electrical Engineering and Computer Science Institute of Renewable Energy Systems

Zur Schwedenschanze 15, 18435 Stralsund, Germany

ORCID ID: 0000-0001-9741-2156

\section{Wojciech Zeńczak}

West Pomeranian University of Technology, Szczecin Faculty of Maritime Technology and Transport Department of Safety and Energy Engineering Aleja Piastów 17, 70-310 Szczecin, Poland e-mail:wojciech.zenczak@zut.edu.pl

ORCID ID: 0000-0003-3925-3323

\section{Daniel Łuszczyński}

West Pomeranian University of Technology, Szczecin Faculty of Maritime Technology and Transport Department of Safety and Energy Engineering Aleja Piastów 17, 70-310 Szczecin, Poland ORCID ID: 0000-0001-7463-0652
[13] J.P. Minier. "Statistical Description of polydisperse turbulent two-phase flows". Physics Reports, Volume 665, pp. 1122, Dec. 2016.

[14] M. Rozmarynowska. "LNG jako alternatywne paliwo dla statków-aspekty techniczne, ekologiczne, ekonomiczne, i regulacyjne". Logistyka, No. 5, pp. 741-748, 2012.

[15] A. S. Foroushani, M.N. Esfahany. "CFD Simulation of GasSolid Two-Phase Flow in Pneumatic Conveying of Wheat". Iran. J. Chem. Chem. Eng. Vol. 34, No. 4, pp. 123-140, 2015. 